\title{
Growth and Yield of Foxtail Millet [Setaria italica (L.)] Varieties to Different Nitrogen Levels
}

\author{
G. Ravindranadh", M. SreeRekha, B. Venkateswarlu and K. Jayalalitha \\ Department of Agronomy, Agricultural College, Bapatla-522101, India \\ *Corresponding author
}

\section{A B S T R A C T}

\begin{tabular}{|l|}
\hline Ke y w or d s \\
Foxtail millet, \\
$\begin{array}{l}\text { Varieties, Nitrogen } \\
\text { levels }\end{array}$ \\
\hline Article Info \\
\hline $\begin{array}{l}\text { Accepted: } \\
\text { 07 October } 2019 \\
\text { Available Online: } \\
\text { 10 November 2019 }\end{array}$ \\
\hline
\end{tabular}

\section{Introduction}

"Millets are named as 'nutraceuticals' as they provide dietary fibres, minerals, vitamins, proteins, antioxidants, and energy which benefit the health status of human". These small millets aid and confront the people of arid and semi-arid regions in making sound and stable management under increasing evidence of low seasonal rainfall, increase in temperature and frequent occurrence of extreme weather conditions.

They are the poor man's food particularly in the dry regions of the world and also supply a large amount of soft straw for the milch and draught animals. The present climatic conditions and the added advantages of small millets necessitate the exploitation of the underutilized crops viz., foxtail millet, fingermillet, proso millet, barnyard millet and little millet. Foxtail millet contains a high amount of protein $(11 \%)$ and fat $(4 \%)$. The protein fractions are represented by albumins and globulins $(13 \%)$, prolamins $(39.4 \%)$, and glutelins (9.9\%).

It is thus recommended as an ideal food for diabetics. It also contains significant amounts of potential antioxidants like phenols, phenolic acids, and carotenoids (Saleh et al., 2013; Zhang and Liu, 2015). Millets are therefore, consumed as multi-grains to reap the collective health benefits of nutrients. 
Foxtail millet (Setariaitalica), known as Italian millet, is confined to lower Deccan plateau including highlands of Karnataka, Andhra Pradesh, Uttarakhand and Tamil Nadu accounting for $90 \%$ area in the country. According to the recent studies, newly developed varieties of foxtail millet are more responsive to nitrogenous fertilizers (AICSMIP, 2013). The maximum yield potential can be achieved by growing high yielding varieties with effective nitrogen management.

\section{Materials and Methods}

Experiment was carried out on sandy clay soils of Agricultural College Farm, Bapatla during kharif, 2018. The soil was neutral in soil reaction, very low in available nitrogen and medium in organic carbon and available phosphorus, very high in available potassium. The experiment was laid out in randomized block design with factorial concept. The treatments consisted of four varieties Prasad $\left(\mathrm{V}_{1}\right)$, Narasimharaya $\left(\mathrm{V}_{2}\right)$, SiA $3156\left(\mathrm{~V}_{3}\right)$ and CO-2 $\left(\mathrm{V}_{4}\right)$ and four nitrogen levels viz., $0 \mathrm{~kg}$ $\mathrm{N}$ ha $^{-1}\left(\mathrm{~N}_{1}\right), 20 \mathrm{~kg} \mathrm{ha}^{-1}\left(\mathrm{~N}_{2}\right), 40 \mathrm{~kg} \mathrm{ha}^{-1}\left(\mathrm{~N}_{3}\right)$ and $60 \mathrm{~kg} \mathrm{ha}^{-1}\left(\mathrm{~N}_{4}\right)$ replicated thrice.

The crop was sown at $30 \mathrm{~cm}$ and $10 \mathrm{~cm}$ inter and intra row distance on 06.09.2018, respectively and adopted all the standard package of practices. A total of $187.2 \mathrm{~mm}$ rainfall was received in 14 rainy days during the crop growth period. The entire dose of phosphorus@20 kg ha ${ }^{-1}$ was applied uniformly to all plots as basal. The scheduled nitrogen was applied in two equal splits as per the treatments viz., half as basal and remaining half as top dressing at 30DAS. The data on plant height, drymatter accumulation, tillers $\mathrm{m}^{-2}$, yield attributes and yield were recorded as per standard procedures. The data was analyzed by following the analysis of variance (ANOVA) for randomized block design with factorial concept.

\section{Results and Discussion}

\section{Plant height at different stages $(\mathrm{cm})$}

At 30 DAS, plant height of different foxtail millet varieties viz., Prasad $\left(\mathrm{V}_{1}\right)$, Narasimharaya $\left(\mathrm{V}_{2}\right)$, SiA $3156\left(\mathrm{~V}_{3}\right)$ and CO-2 $\left(\mathrm{V}_{4}\right)$ could not reach the level of significance. Narasimharaya variety $\left(\mathrm{V}_{2}\right)$ resulted in significantly taller plants $(118.2 \mathrm{~cm})$ over $\mathrm{SiA}$ 3156 variety $\left(\mathrm{V}_{3}\right)$ which had the shortest plants $(103.1 \mathrm{~cm})$. However, the plant height of Narasimharaya $\left(\mathrm{V}_{2}\right)$ was statistically on par with the remaining two varieties i.e., Prasad $\left(\mathrm{V}_{1}\right)$ and CO-2 $\left(\mathrm{V}_{4}\right)$ at 60 DAS. At harvest, significantly taller plants with equal plant height $(126.3 \mathrm{~cm})$ was found in both the varieties i.e., Narasimharaya $\left(\mathrm{V}_{2}\right)$ and Prasad $\left(\mathrm{V}_{1}\right)$ over $\mathrm{SiA} 3156$ variety $\left(\mathrm{V}_{3}\right)$ which produced the shortest plants. However, $\mathrm{V}_{2}$ and $\mathrm{V}_{1}$ varieties were on par with $\mathrm{V}_{4}$ variety (Table 1). This variation in plant height of different foxtail millet varieties could be attributed to difference in genetic makeup of the varieties. The results reported are in conformity with the findings of Radha Kumari et al., (2017), Shanthi et al., (2017) and Mahajan et al., (2017). Increase in nitrogen levels from 0 to $60 \mathrm{~kg} \mathrm{ha}^{-1}$ resulted in increased plant height. However, statistical significance was not found among the nitrogen levels tried at 30 DAS. The highest nitrogen level i.e., $60 \mathrm{~kg} \mathrm{ha}{ }^{-1}\left(\mathrm{~N}_{4}\right)$ resulted in production of maximum plant height (121.2 $\mathrm{cm}$ ) which was significantly superior over 0 $\mathrm{kg} \mathrm{N} \mathrm{ha}{ }^{-1}\left(\mathrm{~N}_{1}\right)$ level, which produced the shortest plants $(97.3 \mathrm{~cm})$. However, plant height of $\mathrm{N}_{4}$ was on par with $\mathrm{N}_{3}$ and $\mathrm{N}_{2}$ application at 60 DAS (Table 1). The least plant height $(104.2 \mathrm{~cm})$ was produced with 0 $\mathrm{kg} \mathrm{N} \mathrm{ha}^{-1}\left(\mathrm{~N}_{1}\right)$ which was significantly inferior over $60 \mathrm{~kg} \mathrm{~N}^{-1}\left(\mathrm{~N}_{4}\right)(129.8 \mathrm{~cm})$. However, the plant height at $\mathrm{N}_{4}$ was statistically on par with $\mathrm{N}_{3}(127.9 \mathrm{~cm})$ and $\mathrm{N}_{2}(125.8 \mathrm{~cm})$ at harvest. Increase in plant height with increase in nitrogen levels from 0 to $60 \mathrm{~kg} \mathrm{ha}^{-1}$ might 
be due to boosting of cellular division, production of growth promoting hormones, meristematic activity combined with increase in length and size of cells and intercellular spaces producing longer plants. The results are in consonance with the findings of Ramyasri (2018), RadhaKumari et al., (2017) and Shanthi et al., (2017).

\section{Number of tillers $\mathbf{m}^{-2}$ at different stages}

There was significant increase in number of tillers $\mathrm{m}^{-2}$ produced with advancement of crop upto 60 DAS and then decrease in number of tillers $\mathrm{m}^{-2}$ was noticed at harvest, which was due to senescence of the crop. Among the four varieties, number of tillers $\mathrm{m}^{-2}$ of Prasad $\left(\mathrm{V}_{1}\right)$ (41.3) was significantly superior over the remaining varieties viz., Narasimharaya $\left(\mathrm{V}_{2}\right)$, $\mathrm{SiA} 3156\left(\mathrm{~V}_{3}\right)$ and $\mathrm{CO}-2\left(\mathrm{~V}_{4}\right)$ at $30 \mathrm{DAS}$, the least (35.2) were produced by CO-2 variety $\left(\mathrm{V}_{4}\right)$. At 60 DAS and harvest, irrespective of the variety chosen, number of tillers $\mathrm{m}^{-2}$ were statistically non-significant (Table 2). Prasad variety $\left(\mathrm{V}_{1}\right)$ was found to be the highest total tiller producer at all growth stages and this variation in tiller production might be attributed to difference in genetic potential of the varieties. These results were reported in similar way by Ramyasri (2018), RadhaKumari et al., (2017) and Mahajan et al., (2017).

Nitrogen levels had significant influence on number of tillers $\mathrm{m}^{-2}$, with increase in nitrogen levels from $0\left(\mathrm{~N}_{1}\right)$ to $60 \mathrm{~kg}\left(\mathrm{~N}_{4}\right) \mathrm{ha}^{-1}$. Application of higher dose of nitrogen i.e., 60 $\mathrm{kg} \mathrm{ha}^{-1}\left(\mathrm{~N}_{4}\right)$ resulted in the maximum tillers $\mathrm{m}^{-}$ 2 during the entire crop growth. At 30, 60 DAS and at harvest, $\mathrm{N}_{4}$ treatment produced significantly more number of tillers $\mathrm{m}^{-2}$ (46.1, 112.3 and 105.1, respectively) over the remaining nitrogen levels viz., $40 \mathrm{~kg} \mathrm{ha}^{-1}\left(\mathrm{~N}_{3}\right)$, $20 \mathrm{~kg} \mathrm{ha}\left(\mathrm{N}_{2}\right)$ and $0 \mathrm{~kg} \mathrm{ha}^{-1}\left(\mathrm{~N}_{1}\right)$. Significantly, least number (29.0, 72.2 and 60.9 at 30, 60 DAS and at harvest, respectively) were produced with no nitrogen application $\left(\mathrm{N}_{1}\right)$. Irrespective of growth stages, the produced number of tillers was the least with no nitrogen application $\left(\mathrm{N}_{1}\right)$ (Table 2). Nitrogen role in increased supply of auxins, synthesis of growth promoting hormones like cytokinin enhanced the production and activation of tiller buds of all the shoot nodes might be the reason for production of significantly more number of tillers $\mathrm{m}^{-2}$ with the maximum nitrogen application of $60 \mathrm{~kg} \mathrm{~N}$ $\mathrm{ha}^{-1}\left(\mathrm{~N}_{4}\right)$. These findings are in consonance with Ramyasri (2018) and Raundal and Patil (2017).

\section{Drymatter accumulation at different stages $\left(\mathrm{kg} \mathrm{ha}^{-1}\right)$}

As the initial plant growth was very slow, variation in drymatter accumulation of four foxtail millet varieties was non-significant at 30 DAS. Irrespective of the foxtail millet varieties and nitrogen levels, there was steep increase in drymatter accumulation from 30 DAS to 60 DAS. Drymatter accumulation of Prasad (2427 kg ha $\left.{ }^{-1}\right)$ was significantly superior over CO-2 (1705 $\left.\mathrm{kg} \mathrm{ha}^{-1}\right)$, which accumulated the lowest drymatter. However, the drymatter accumulation of Prasad was on par with Narasimharaya (2418 $\mathrm{kg} \mathrm{ha}^{-1}$ ) and SiA 3156 (2046 $\left.\mathrm{kg} \mathrm{ha}^{-1}\right)$ at 60 DAS. At harvest, maximum drymatter accumulation (4024 $\left.\mathrm{kg} \mathrm{ha}^{-1}\right)$ was noticed in Prasad $\left(\mathrm{V}_{1}\right)$ which was significantly superior to Narasimharaya $\left(\mathrm{V}_{2}\right)$, SiA $3156\left(\mathrm{~V}_{3}\right)$ and CO-2 $\left(\mathrm{V}_{4}\right)$, which accumulated the lowest drymatter (2829 $\left.\mathrm{kg} \mathrm{ha}^{-1}\right)$. However, the drymatter accumulation of Narasimharaya was on par with SiA 3156 (Table 3). Maximum drymatter accumulation in Prasad variety $\left(\mathrm{V}_{1}\right)$ might be attributed due to production of more number of tillers and genetic character for higher photosynthetic capacity. The results were in conformity with the findings of Raundal and Patil (2017) and Jyothiet al., (2016). 
Table.1 Plant height $(\mathrm{cm})$ of foxtail millet varieties as influenced by varieties and nitrogen levels

\begin{tabular}{|c|c|c|c|}
\hline Treatments & 30 DAS & 60 DAS & At harvest \\
\hline \multicolumn{4}{|c|}{ Varieties } \\
\hline$V_{1}-$ Prasad & 53.8 & 117.3 & 126.3 \\
\hline $\mathbf{V}_{2}$ - Narasimharaya & 57.4 & 118.2 & 126.3 \\
\hline$V_{3}-\operatorname{SiA} 3156$ & 55.1 & 103.1 & 111.8 \\
\hline $\mathrm{V}_{4}-\mathrm{CO}-2$ & 53.6 & 114.0 & 123.4 \\
\hline SEm \pm & 1.94 & 2.56 & 3.77 \\
\hline $\mathrm{CD}(\mathrm{P}=0.05)$ & NS & 7.4 & 10.8 \\
\hline \multicolumn{4}{|c|}{ Nitrogen levels $\left(\mathrm{kg} \mathrm{ha}^{-1}\right)$} \\
\hline $\mathbf{N}_{1}-\mathbf{0}$ & 52.2 & 97.3 & 104.2 \\
\hline$N_{2}-20$ & 55.1 & 116.4 & 125.8 \\
\hline$N_{3}-40$ & 56.1 & 117.8 & 127.9 \\
\hline$N_{4}-60$ & 56.5 & 121.2 & 129.8 \\
\hline SEm \pm & 1.94 & 2.56 & 3.77 \\
\hline $\mathrm{CD}(\mathrm{P}=\mathbf{0 . 0 5})$ & NS & 7.4 & 10.8 \\
\hline \multicolumn{4}{|c|}{ Interaction $(\mathbf{V} \times \mathbf{N})$} \\
\hline SEm \pm & 3.87 & 5.12 & 7.54 \\
\hline $\mathrm{CD}(\mathrm{P}=\mathbf{0 . 0 5})$ & NS & NS & NS \\
\hline CV\% & 12.2 & 7.8 & 10.7 \\
\hline
\end{tabular}

Table.2 Number of tillers $\mathrm{m}^{-2}$ and effective tillers $\mathrm{m}^{-2}$ of foxtail millet varieties as influenced by nitrogen levels

\begin{tabular}{|c|c|c|c|c|}
\hline \multirow[t]{2}{*}{ Treatments } & \multicolumn{3}{|c|}{ Number of tillers $\mathbf{m}^{-2}$} & \multirow{2}{*}{$\begin{array}{c}\text { Number of } \\
\text { effective tillers m }\end{array}$} \\
\hline & 30 DAS & 60 DAS & At Harvest & \\
\hline \multicolumn{5}{|c|}{ Varieties } \\
\hline$V_{1}-$ Prasad & 41.3 & 97.4 & 87.7 & 43.5 \\
\hline $\mathrm{V}_{2}$ - Narasimharaya & 37.6 & 92.8 & 84.2 & 39.0 \\
\hline$V_{3}-\mathrm{SiA} 3156$ & 36.2 & 91.1 & 83.3 & 35.6 \\
\hline $\mathrm{V}_{4}-\mathrm{CO}-2$ & 35.2 & 89.7 & 82.1 & 33.5 \\
\hline SEm \pm & 0.70 & 2.55 & 1.09 & 0.81 \\
\hline $\mathrm{CD}(\mathrm{P}=0.05)$ & 2.0 & NS & NS & 2.3 \\
\hline \multicolumn{5}{|c|}{ Nitrogen levels $\left(\mathrm{kg} \mathrm{ha}^{-1}\right)$} \\
\hline$N_{1}-0$ & 29.0 & 72.2 & 60.9 & 24.5 \\
\hline$N_{2}-20$ & 33.9 & 85.4 & 75.6 & 37.1 \\
\hline$N_{3}-40$ & 41.4 & 101.1 & 95.8 & 43.5 \\
\hline$N_{4}-60$ & 46.1 & 112.3 & 105.1 & 46.0 \\
\hline SEm \pm & 0.70 & 2.55 & 1.09 & 0.81 \\
\hline $\mathrm{CD}(\mathrm{P}=\mathbf{0 . 0 5})$ & 2.0 & 7.3 & 3.1 & 2.3 \\
\hline \multicolumn{5}{|c|}{ Interaction $(\mathbf{V} \times \mathbf{N})$} \\
\hline SEm \pm & 1.39 & 5.09 & 2.18 & 1.62 \\
\hline $\mathrm{CD}(\mathrm{P}=\mathbf{0 . 0 5})$ & NS & NS & $\mathrm{NS}$ & NS \\
\hline CV\% & 10.8 & 9.5 & 7.4 & 7.5 \\
\hline
\end{tabular}


Table.3 Drymatter accumulation $\left(\mathrm{kg} \mathrm{ha}^{-1}\right)$ of foxtail millet varieties as influenced by nitrogen levels

\begin{tabular}{|c|c|c|c|}
\hline Treatments & 30 DAS & 60 DAS & At harvest \\
\hline \multicolumn{4}{|c|}{ Varieties } \\
\hline$V_{1}-$ Prasad & 694 & 2427 & 4024 \\
\hline $\mathbf{V}_{2}-$ Narasimharaya & 662 & 2418 & 3613 \\
\hline$V_{3}-\operatorname{SiA} 3156$ & 670 & 2046 & 3451 \\
\hline $\mathrm{V}_{4}-\mathrm{CO}-2$ & 644 & 1705 & 2829 \\
\hline SEm \pm & 12.2 & 135.5 & 138.8 \\
\hline $\mathrm{CD}(\mathrm{P}=0.05)$ & NS & 391 & 401 \\
\hline \multicolumn{4}{|c|}{ Nitrogen levels $\left(\mathrm{kg} \mathrm{ha}^{-1}\right)$} \\
\hline$N_{1}-0$ & 653 & 1539 & 2364 \\
\hline $\mathbf{N}_{2}-20$ & 661 & 2266 & 3480 \\
\hline$N_{3}-40$ & 672 & 2367 & 3950 \\
\hline$N_{4}-60$ & 685 & 2424 & 4122 \\
\hline SEm \pm & 12.2 & 135.5 & 138.8 \\
\hline $\mathrm{CD}(\mathrm{P}=0.05)$ & NS & 391 & 401 \\
\hline \multicolumn{4}{|c|}{ Interaction $(\mathbf{V} \times \mathbf{N})$} \\
\hline SEm \pm & 24.3 & 270.9 & 277.7 \\
\hline $\mathrm{CD}(\mathrm{P}=\mathbf{0 . 0 5})$ & NS & NS & NS \\
\hline CV\% & 16.3 & 18.5 & 13.8 \\
\hline
\end{tabular}

Table.4 1000 grain weight $(\mathrm{g})$, grain and stover yield $\left(\mathrm{kg} \mathrm{ha}^{-1}\right)$ of foxtail millet varieties as influenced by nitrogen levels

\begin{tabular}{|c|c|c|c|}
\hline Treatments & $\begin{array}{l}1000 \text { grain } \\
\text { weight }(\mathrm{g})\end{array}$ & Grain yield (kg ha $\left.{ }^{-1}\right)$ & Stover yield $\left(\mathrm{kg} \mathrm{ha}^{-1}\right)$ \\
\hline \multicolumn{4}{|c|}{ Varieties } \\
\hline $\mathrm{V}_{1}-$ Prasad & 3.65 & 1609 & 2405 \\
\hline$V_{2}$ - Narasimharaya & 3.11 & 1402 & 2201 \\
\hline$V_{3}-\operatorname{SiA} 3156$ & 3.55 & 1366 & 2075 \\
\hline $\mathrm{V}_{4}-\mathrm{CO}-2$ & 2.98 & 860 & 1959 \\
\hline SEm \pm & 0.161 & 69.5 & 93.5 \\
\hline $\mathrm{CD}(\mathrm{P}=\mathbf{0 . 0 5})$ & 0.46 & 200 & 270 \\
\hline \multicolumn{4}{|c|}{ Nitrogen levels $\left(\mathrm{kg} \mathrm{ha}^{-1}\right)$} \\
\hline$N_{1}-0$ & 3.02 & 741 & 1612 \\
\hline $\mathbf{N}_{2}-20$ & 3.34 & 1336 & 2134 \\
\hline$N_{3}-40$ & 3.39 & 1514 & 2426 \\
\hline$N_{4}-60$ & 3.55 & 1645 & 2467 \\
\hline SEm \pm & 0.161 & 69.5 & 93.5 \\
\hline $\mathrm{CD}(\mathrm{P}=0.05)$ & NS & 200 & 270 \\
\hline \multicolumn{4}{|c|}{ Interaction $(\mathbf{V} \times \mathbf{N})$} \\
\hline SEm \pm & 0.322 & 138.9 & 187.0 \\
\hline $\mathrm{CD}(\mathrm{P}=0.05)$ & NS & NS & NS \\
\hline CV\% & 16.7 & 18.4 & 15.0 \\
\hline
\end{tabular}


Increase in drymatter accumulation with increase in nitrogen levels from 0 to $60 \mathrm{~kg} \mathrm{ha}^{-}$ ${ }^{1}$ was observed but at 30 DAS drymatter accumulation could not reach the level of significance. Nitrogen level@60 kg ha-1 resulted in accumulation of maximum drymatter $\left(2424 \quad \mathrm{~kg}^{-1}\right)$ which was significantly superior over $0 \mathrm{~kg} \mathrm{~N}^{-1}$ level (1539 $\mathrm{kg} \mathrm{ha}^{-1}$ ). However, minimum drymatter accumulation at $60 \mathrm{DAS}$ was with $0 \mathrm{~kg} \mathrm{~N} \mathrm{ha}^{-1}$. Drymatter accumulation of $\mathrm{N}_{4}$ treatment was on par with $\mathrm{N}_{3}\left(2367 \mathrm{~kg} \mathrm{ha}^{-1}\right)$ and $\mathrm{N}_{2}(2266 \mathrm{~kg}$ $\left.\mathrm{ha}^{-1}\right)$. At harvest, the highest nitrogen level i.e., $60 \mathrm{~kg} \mathrm{ha}^{-1}$ resulted in maximum drymatter accumulation (4122 $\mathrm{kg} \mathrm{ha}^{-1}$ ) which was significantly superior over $20 \mathrm{~kg} \mathrm{~N} \mathrm{ha}^{-1}$ and 0 $\mathrm{kg} \mathrm{N}$ ha $^{-1}$ levels, which resulted in minimum drymatter accumulation $\left(2364 \mathrm{~kg} \mathrm{ha}^{-1}\right.$ ) (Table 3). However, drymatter accumulation of $\mathrm{N}_{4}$ treatment was on par with $\mathrm{N}_{3}$. Drymatter accumulation with $60 \mathrm{~kg} \mathrm{~N} \mathrm{ha}^{-1}$ was higher by $4.4 \%, 18.4 \%$ and $74.4 \%$ over $40 \mathrm{~kg} \mathrm{~N} \mathrm{ha}^{-1}, 20$ $\mathrm{kg} \mathrm{N} \mathrm{ha}{ }^{-1}$ and no nitrogen application, respectively. Increase in drymatter accumulation with increase in nitrogen levels from 0 to $60 \mathrm{~kg} \mathrm{ha}^{-1}$ might be due to production of more number of nitrogenous compounds like amino acids, proteins, protoplasm, photosynthates at higher $\mathrm{N}$ level. These results were in consonance with the findings of Nagarajan et al., (2018) and Jyothi et al., (2016).

\section{Yield Attributes}

Significantly higher number of effective tillers $\mathrm{m}^{-2}$ (43.5) (Table 2) and1000 grain weight (3.65 g) (Table 4) were recorded by Prasad, while the minimum $(33.5$ and $2.98 \mathrm{~g}$, respectively) were registered with $\mathrm{CO}-2$. Maximum number of effective tillers $\mathrm{m}^{-2}$ (46.0) were produced with higher $\mathrm{N} @ 60 \mathrm{~kg}$ $\mathrm{ha}^{-1}$ which was significantly superior over all the remaining $\mathrm{N}$ levels, while the minimum was noticed with no nitrogen application. Nitrogen levels could not reach the level of significance with regard to 1000 grain weight (g).

\section{Yield $\left(\mathrm{kg} \mathrm{ha}^{-1}\right)$}

Among the varieties, Prasad variety $\left(\mathrm{V}_{1}\right)$ gave significantly higher grain yield (1609 $\left.\mathrm{kg} \mathrm{ha}^{-1}\right)$ and shown its statistical supremacy over the remaining three varieties. The lowest grain yield was recorded by CO-2 (860 kg ha $\left.{ }^{-1}\right)$. Nitrogen@60 kg ha ${ }^{-1}$ resulted in maximum grain yield (1645 kg ha $\mathrm{kg}^{-1}$ and was significantly superior over $20 \mathrm{~kg} \mathrm{~N} \mathrm{ha}^{-1}$ and no nitrogen levels (741 kg ha $\left.{ }^{-1}\right)$. However, it was on par with grain yield@ 40 kg N ha ${ }^{-1}$ (Table 4).

With respect to stover yield, Prasad variety $\left(2405 \mathrm{~kg} \mathrm{ha}^{-1}\right)$ produced maximum and was significantly superior over SiA 3156 and CO-2 varieties, which recorded the lower stover yield (1959 kg ha $\left.{ }^{-1}\right)$. However, stover yield of Prasad was on par with Narasimharaya. Among the nitrogen levels, the maximum stover yield was produced with $60 \mathrm{~kg} \mathrm{~N}^{-1}$ application (2467 $\left.\mathrm{kg} \mathrm{ha} \mathrm{ha}^{-1}\right)$ which was significantly superior over $20 \mathrm{~kg} \mathrm{~N}$ and $0 \mathrm{~kg} \mathrm{~N}$ $\mathrm{ha}^{-1}$, which resulted in significantly lower stover yield (1612 $\mathrm{kg} \mathrm{ha}{ }^{-1}$ ) (Table 4). However, stover yield obtained with $\mathrm{N}_{4}$ treatment was statistically on par with $\mathrm{N}_{3}$ treatment.

Significant superiority of Prasad variety for both grain and stover yields might be due to its genetic constitution of yield attributing morpho-physiological parameters and maximum drymatter content. Similar results were also expressed by Ramyasri et al., (2018), Shanthiet al., (2017) and Jyothi et al., (2016).

There was nointeraction effect between varieties and nitrogen levels for all parameters studied. It can be concluded that Prasad variety of foxtail millet performed well 
resulting in highest drymatter accumulation, yield parameters and yield and among the nitrogen levels, $60 \mathrm{~kg} \mathrm{~N}^{-1}$ resulted in higher yields. However, it was on par with $40 \mathrm{~kg} \mathrm{~N}$ $\mathrm{ha}^{-1}$.

\section{References}

AICSMIP (All India Co-ordinated Small Millets Improvement Project). (2013). Annual Report (2012-2013), project coordinating unit on small millets, ICAR, GKVK, Bangalore. pp. AG 3637.

Jyothi, K.N., Sumathi, V and Sunitha, N. (2016). Productivity, nutrient balance and profitability of foxtail millet varieties as influenced by levels of nitrogen. IOSR Journal of Agriculture and Veterinary Science. 9 (4): 18-22.

Mahajan, G., Pushplatha, T and Singh, D. (2017). Response of kodo millet varieties to different fertility levels under rainfed conditions of kymore plateau. Environment \& Ecology. 35 (2B): 10181021.

Nagarajan, G., Ramesh, T., Janaki, P and Rathika, S. (2018). Enhancement of fingermillet productivity through land configuration and nitrogen management under sodic soil. Madras Agricultural Journal. 105 (7-9): 257-261.

RadhaKumari, C., Shanthi, P., Niveditha, M., Sudheer, K.V.S., Reddy, P.K.Y and Reddy, S.B. (2017). Identification of suitable foxtail millet variety for rainfed alfisols of scarce rainfall zone. Journal on Research ANGRAU. 45 (1): 1-6.

Ramyasri, K. (2018). Performance of Foxtail Millet Varieties under Different Nitrogen Levels in Rice-Fallow. M.Sc. (Ag.) Thesis. Acharya NG Ranga Agricultural University, Guntur.

Ramyasri, K., Ramana, A.V., Upendra Rao, A and Guru Murthy, P. (2018). Nutrient uptake vis a vis grain yield of foxtail millet varieties as influenced by nitrogen levels in rice fallows. International Journal of Current Microbiology and Applied Sciences. 7 (9): 2626-2629.

Raundal, P.U and Patil V.U. (2017). Response of little millet varieties to different levels of fertilizers under rainfed condition. International Advanced Research Journal in Science, Engineering and Technology. 4 (8): 55-58.

Saleh, A. S. M., Zhang, Q., Chen, J and Shen, Q. (2013). Millet grains: nutritional quality, processing, and potential health benefits. Comprehensive reviews in food science and food safety. 12: 281-295.

Shanthi, P., RadhaKumari, C., Niveditha, M, Reddy, P.K.Y and Reddy, S. (2017). Genetic variability studies in Italian millet (Setariaitalica (L.) Beauv) varieties under rainfed conditions in scarce rainfall zone of Andhra Pradesh. The Andhra Agricultural Journal. 64 (2): 330-334.

Zhang, L. Z and Liu, R. H. (2015). Phenolic and carotenoid profiles and antiproliferative activity of foxtail millet. Food chemistry. 174: 495-501.

\section{How to cite this article:}

Ravindranadh, G., M. SreeRekha, B. Venkateswarlu and Jayalalitha, K. 2019. Growth and Yield of Foxtail Millet [Setaria italica (L.)] Varieties to Different Nitrogen Levels. Int.J.Curr.Microbiol.App.Sci. 8(11): 698-704. doi: https://doi.org/10.20546/ijcmas.2019.811.084 